\title{
Nitrogen Application Frequency for Drip-irrigated Tomatoes
}

\author{
Wilton P. Cook \\ Coastal Research and Education Center, Clemson University, 2865 \\ Savannah Highway, Charleston, SC 29414 \\ Douglas C. Sanders \\ Department of Horticultural Sciences, North Carolina State University, \\ Raleigh, NC 27695-7609
}

Additional index words. foliage $\mathrm{N}$ concentration, soil nitrate levels, Lycopersicon esculentum

\begin{abstract}
Studies were conducted to determine the effect of $\mathbf{N}$ application frequency through drip irrigation on soil $\mathrm{NO}_{3}-\mathrm{N}$ movement in the bed profile and on yield and $\mathbf{N}$ uptake by tomato plants (Lycopersicon esculentum Mill. 'Sunny') at two locations. Increasing $\mathbf{N}$ application frequency resulted in increased yields at Clayton, $\mathbf{N}$. $C$., but not at Charleston, S.C. The number of fruit produced was not affected by $\mathbf{N}$ treatment at either location, but fruit size increased with increasing $\mathbf{N}$ application frequency at Clayton. Foliage $\mathbf{N}$ concentration decreased seasonally, but neither foliage $\mathbf{N}$ concentration nor total $\mathrm{N}$ content of the above-ground portion of the plants was affected by $\mathrm{N}$ application frequency. Regardless of $\mathrm{N}$ application frequency, $\mathrm{NO}_{3}-\mathrm{N}$ concentrations within the raised bed decreased with time due to plant uptake and leaching. Nitrogen levels declined most rapidly in the area closest to the drip tube.
\end{abstract}

Drip irrigation is an effective method of supplying water (Bhella, 1986; Doss et al., 1980; Elmstrom et al., 1981; Hall, 1974; Karlen and Robbins, 1983) and soluble nutrients to plants growing on a polyethylenemulch-covered bed (Fiskell and Locascio, 1983; Locascio and Myers, 1974; Miller et al., 1981). Locascio et al. (1977) reported highest yields of strawberries with $50 \%$ of the $\mathrm{N}$ and $\mathrm{K}$ applied preplant and 50\% applied through the drip irrigation tube. Isobe (1974), working with sugarcane, found greater efficiency and greater dry matter accumulation with daily vs. biweekly applications of N. Bhella (1986) reported yield increases with muskmelons when $\mathrm{N}$ was added postplant through the drip irrigation tube. A potential problem associated with drip irrigation is leaching of nutrients. Bar-Yosef (1977) and Bernstein and Francois (1973) demonstrated that ions move with the irrigation water away from the injection site. This movement could

Received for publication 19 Mar. 1990. Paper no. 12118 of the Journal Series of the North Carolina Agricultural Research Service, Raleigh, NC 276957643. The use of trade names in this publication does not imply endorsement by the North Carolina Agricultural Research Service of the products named, nor criticism of similar ones not mentioned. Partial funding for this research is from the U.S. Dept. of Agriculture Special Grant P.L. 89-106: "Agricultural Adjustment in the Southeast Through Alternative Cropping Systems." Additional funding was from a grant by the South Carolina Tomato Growers Assn. We gratefully acknowledge the support of the Asgrow Seed Co., Hendrix and Dail Co., and the staffs of the Central Crops Research Station and the Coastal Research and Education Center. The cost of publishing this paper was defrayed in part by the payment of page charges. Under postal regulations, this paper therefore must be hereby marked advertisement solely to indicate this fact. result in nutrient deficiencies in the root zone.

Our studies were conducted to determine the effect of $\mathrm{N}$ application frequency through drip irrigation tubing on $\mathrm{NO}_{3}-\mathrm{N}$ movement and accumulation in the bed profile. Resulting uptake and use by tomatoes growing under a full-bed, polyethylene-mulch production system (Cook et al., 1980) also were studied.

Experiments were conducted at Charleston, S. C., on a Yauhannah (Aquic Hapudult) loamy fine sand $[\mathrm{pH} 6.3$, organic matter (OM) $1.2 \%$ ] and at Clayton, N. C., on a Norfolk (Typic Paleudults) loamy sand (pH 6.2, OM $0.4 \%$ ). Phosphorus and $\mathrm{K}$ levels tested medium at both locations. Experimental design was a randomized complete block with five treatments and four replications. Analyses of variance were performed and significant means separated by LSD. Plots were three rows (beds) wide and $12 \mathrm{~m}$ long, with the two outer rows serving as guard rows.

All plots received a preplant fertilizer application of $54 \mathrm{P}-214 \mathrm{~K}\left(\mathrm{~kg} \cdot \mathrm{ha}^{-1}\right)$. Control plots received $157 \mathrm{~kg} \mathrm{~N} / \mathrm{ha}$ preplant as $\mathrm{Ca}\left(\mathrm{NO}_{3}\right) 2$. All other treatments received an equivalent amount of total $\mathrm{N}$ supplied equally in monthly, biweekly, weekly, or daily applications $(3,6,12$, or 84 applications, respectively) through the drip tube. Preplant fertilizers were broadcast on preformed beds and incorporated; the beds then were fumigated with $98 \%$ methyl bromide- $2 \%$ chloropicrin at $336 \mathrm{~kg} \cdot \mathrm{ha}^{-1}$ and covered with $0.04-$ $\mathrm{mm}$ black polyethylene mulch. A single drip irrigation tube [T-TAPE (T-Systems Intl., San Diego) low flow tape with $20-\mathrm{cm}$ orifice spacing] was placed on the left side of the bed $12 \mathrm{~cm}$ from the bed center at a depth of $4 \mathrm{~cm}$ as the mulch was laid.

Six-week-old 'Sunny' tomato seedlings were transplanted in the bed center at
Charleston on 3 Apr. at an in-row spacing of $0.6 \mathrm{~m}$ with $1.8 \mathrm{~m}$ between rows $(9258$ plants/ha) and at Clayton on 29 Apr. at a spacing of $0.6 \times 1.5 \mathrm{~m}(11,110$ plants/ha $)$. Beds were $0.9 \mathrm{~m}$ wide and $0.1 \mathrm{~m}$ high at both locations. Dry soil within the bed necessitated a 3 -h preplant irrigation at Clayton.

Soil samples were taken at 30-day intervals at the 0 - to $15-\mathrm{cm}$ and $15-$ to $30-\mathrm{cm}$ depth at the bed center and $30 \mathrm{~cm}$ to either side of bed center to monitor $\mathrm{N}$ movement. Nitrate- $\mathrm{N}$ concentrations were determined using an ion-specific electrode (Keeney and Nelson, 1982).

Calcium nitrate was used as the $\mathrm{N}$ source and was applied by a Venturi type injector. Lines were pressurized for $15 \mathrm{~min}$ before and after injection. All plots were irrigated daily with scheduled $\mathrm{N}$ treatments applied during this irrigation. Additional irrigation was automatically applied as needed at each of the two locations by electrical switching tensiometers when the soil moisture deficit exceeded - $2 \mathrm{kPa}$. Consequently, all plots within a location received an equivalent amount of water each day, regardless of $\mathrm{N}$ treatment. Two weeks after transplanting, all plots required irrigation in addition to that applied during fertilizer application.

Mature green fruit were harvested twice, graded, and mechanically sized: small ( $>54$, $<58 \mathrm{~mm}$ ), medium ( >58, <64 mm), or large (> $64 \mathrm{~mm}$ ). At each harvest, randomly selected fruit were sliced into 5-mm segments, dried at $70 \mathrm{C}$, and stored for later $\mathrm{N}$ analysis. Foliage samples, consisting of 10 recently matured leaves, were collected monthly and dried. After final harvest, three plants were severed at the soil line. Each plant was then weighed, divided into thirds, and equal-size representative samples collected from the top, middle, and bottom third of each plant. These composite samples were dried at 70C and $\mathrm{N}$ content determined. Standard Kjeldahl procedures (Tecator Manual, 1982) were used to determine $\mathrm{N}$ content of all samples. $\mathrm{Re}$ sults from these composite plant samples, along with data from previously harvested fruit, were used to calculate total $\mathrm{N}$ uptake.

The number of $\mathrm{N}$ applications applied through the drip irrigation tube had no effect on number of marketable fruit at either location (range 237,000 to 244,000 at Charleston; Clayton, Table 1). At Clayton, total marketable yields increased directly with increasing frequency of $\mathrm{N}$ application $\left(r^{2}=\right.$ $0.96)$ due to increased yields of large fruit. Yields (42.0 to $46.8 \mathrm{t} \cdot \mathrm{ha}^{-1}$ ) and fruit size distribution (40.1 to $44.4 \mathrm{t} \cdot \mathrm{ha}^{-1}$ for large) were not affected by $\mathrm{N}$ application at Charleston.

The number of $\mathrm{N}$ applications had no effect on the $\mathrm{N}$ concentration of leaf tissue (Table 2) or on the total $\mathrm{N}$ uptake by the above-ground portion of the plant (data not shown) at either location. Total $\mathrm{N}$ uptake was greater at Charleston than at Clayton (278 vs. $213 \mathrm{~kg} \cdot \mathrm{ha}^{-1}$ ), but $\mathrm{N}$ uptake exceeded applied $\mathrm{N}$ at both locations, indicating the plants were able to extract residual $\mathrm{N}$ from the soil. Foliage $\mathrm{N}$ concentrations 
Table 1. The effect of $\mathrm{N}$ application frequency on fruit number and marketable yield of tomatoes at Clayton, N. C. ${ }^{2}$

\begin{tabular}{|c|c|c|c|c|c|}
\hline \multirow{2}{*}{\multicolumn{2}{|c|}{$\mathrm{N}$ application }} & \multicolumn{4}{|c|}{ Marketable yield per hectare } \\
\hline & & \multirow[b]{2}{*}{ Large } & \multirow{2}{*}{$\begin{array}{c}\text { Medium } \\
\text { and } \\
\text { small } \\
\end{array}$} & \multirow[b]{2}{*}{ Total } & \multirow{2}{*}{$\begin{array}{c}\text { Fruit } \\
\text { (thousands) }\end{array}$} \\
\hline Frequency & No. & & & & \\
\hline & & & $(t)$ & & (no.) \\
\hline Preplant & & 31.4 & 7.8 & 39.2 & \\
\hline Monthly & 1 & 34.3 & 6.1 & 40.4 & 258 \\
\hline Biweekly & 6 & 34.4 & 8.3 & 42.7 & 283 \\
\hline Weekly & 12 & 40.6 & 6.8 & 47.4 & 284 \\
\hline Daily & 84 & 44.2 & 6.4 & 50.6 & 288 \\
\hline LSD 0.05 & & 12.7 & NS & 7.6 & NS \\
\hline
\end{tabular}

${ }^{2}$ Small is $>54,<58 \mathrm{~mm}$; medium is $>58,<64 \mathrm{~mm}$; large is $>64 \mathrm{~mm}$.

Table 2. The effect of $\mathrm{N}$ application frequency and sampling sequence on soil and tomato foliage $\mathrm{N}$ concentrations grown at Charleston, S. C., and Clayton, N.C.

\begin{tabular}{|c|c|c|c|c|c|}
\hline \multirow{2}{*}{\multicolumn{2}{|c|}{$\mathrm{N}$ application }} & \multicolumn{4}{|c|}{$\mathrm{N}$ concn ${ }^{2}$} \\
\hline & & \multicolumn{2}{|c|}{$\begin{array}{l}\text { Foliage }^{y} \\
\left(\mathrm{mg} \cdot \mathrm{g}^{-1}\right)\end{array}$} & \multicolumn{2}{|c|}{$\begin{array}{c}\text { Soil NO } \mathrm{NO}^{3} \mathrm{~N} \\
\left(\mathrm{mg} \cdot \mathrm{kg}^{-1}\right)\end{array}$} \\
\hline Frequency & No. & Charleston & Clayton & Charleston & Clayton \\
\hline Preplant & 1 & 39.4 & 34.7 & 16.8 & 11.6 \\
\hline Monthly & 3 & 37.6 & 35.4 & 19.2 & 19.3 \\
\hline Biweekly & 6 & 38.5 & 37.7 & 10.9 & 10.6 \\
\hline Weekly & 12 & 38.5 & 38.0 & 13.0 & 9.6 \\
\hline Daily & 84 & 40.7 & 37.6 & 17.4 & 12.9 \\
\hline LSD 0.05 & & NS & NS & 7.2 & 7.2 \\
\hline \multicolumn{6}{|c|}{ Sampling period ${ }^{x}$} \\
\hline 15 & & 45.9 & 40.3 & 19.2 & 16.8 \\
\hline 45 & & 39.8 & 36.9 & 15.0 & 11.9 \\
\hline 75 & & 31.9 & 32.6 & 11.2 & 9.0 \\
\hline LSD 0.05 & & 3. & 2.7 & 2.0 & 2.3 \\
\hline
\end{tabular}

${ }^{2}$ Averages for four replicates and three sampling dates for foliage and four replicates, two depths, and three sampling dates for soil.

'Means represent average concentrations for all sample locations.

xDays after planting for foliage analysis and days after initial $\mathrm{N}$ application for soil analysis.

Table 3. Seasonal variation in $\mathrm{NO}_{3}-\mathrm{N}$ concentrations in the plant beds at Charleston, S. C., and Clayton, N.C.

\begin{tabular}{|c|c|c|c|c|c|c|}
\hline \multirow{4}{*}{$\begin{array}{l}\text { Sampling location } \\
\text { in bed profile }\end{array}$} & \multicolumn{6}{|c|}{$\mathrm{NO}_{3}-\mathrm{N}$ concn $\left(\mathrm{mg} \cdot \mathrm{kg}^{-1}\right)^{2, y}$} \\
\hline & \multicolumn{3}{|c|}{ Charleston } & \multicolumn{3}{|c|}{ Clayton } \\
\hline & \multicolumn{6}{|c|}{ Days after initial $\mathrm{N}$ application } \\
\hline & 15 & 45 & 75 & 15 & 45 & 75 \\
\hline \multicolumn{7}{|l|}{ Depth } \\
\hline \multicolumn{7}{|l|}{$0-15 \mathrm{~cm}$} \\
\hline Left & $21.6 \mathrm{bc}$ & $16.4 \mathrm{c}$ & $13.8 \mathrm{c}$ & $20.1 \mathrm{bc}$ & $15.3 \mathrm{c}$ & $10.9 \mathrm{~d}$ \\
\hline Center & $28.5 \mathrm{a}$ & $22.8 \mathrm{~b}$ & $9.9 \mathrm{~d}$ & $28.1 \mathrm{a}$ & $16.8 \mathrm{c}$ & $11.5 \mathrm{~cd}$ \\
\hline Right & $29.5 \mathrm{a}$ & $22.6 \mathrm{~b}$ & $21.2 \mathrm{~b}$ & $20.9 \mathrm{bc}$ & $17.2 \mathrm{bc}$ & $15.4 \mathrm{c}$ \\
\hline \multicolumn{7}{|l|}{$15-30 \mathrm{~cm}$} \\
\hline Left & $10.7 \mathrm{~d}$ & $9.8 \mathrm{~d}$ & $7.9 \mathrm{~d}$ & $15.8 \mathrm{c}$ & 9.4 & $5.8 \mathrm{de}$ \\
\hline Center & $12.5 \mathrm{~cd}$ & $9.1 \mathrm{~d}$ & $7.2 \mathrm{~d}$ & $8.6 \mathrm{~d}$ & $6.5 \mathrm{~d}$ & $4.7 \mathrm{e}$ \\
\hline Right & $12.6 \mathrm{~cd}$ & $9.1 \mathrm{~d}$ & $7.2 \mathrm{~d}$ & $7.3 \mathrm{~d}$ & $6.2 \mathrm{~d}$ & $4.9 \mathrm{e}$ \\
\hline
\end{tabular}

${ }^{2}$ Means separated in rows and columns within locations by LSD, $P=0.05$.

'Averaged over four replications and six $\mathrm{N}$ frequency applications.

'Drip tube located just to left of bed center.

decreased as the season progressed but were always within acceptable sufficiency levels (Tanaka et al., 1974).

Soil $\mathrm{NO}_{3}-\mathrm{N}$ concentrations tended to be highest at both locations when the $\mathrm{N}$ was applied monthly or daily (Table 2). The lowest $\mathrm{NO}_{3}-\mathrm{N}$ levels were observed with biweekly or weekly applications. The high $\mathrm{N}$ levels found at both locations when the $\mathrm{N}$ was applied monthly (three applications) may have been unduly influenced by sampling date. With this treatment, sampling always occurred within 10 days after $\mathrm{N}$ application, and excessive leaching probably would not have occurred before sampling. Regardless constant in the right side of the bed at both locations (Table 3). The decrease in $\mathrm{NO}_{3}-\mathrm{N}$ concentration near the drip tube suggests that at least some $\mathrm{NO}_{3}-\mathrm{N}$ was moved out of this area with the irrigation water and would account for the stable $\mathrm{NO}_{3}-\mathrm{N}$ levels in the right side of the bed. Since there was no increase in $\mathrm{NO}_{3}-\mathrm{N}$ levels at the $15-$ to $30-\mathrm{cm}$ depth, most of the decrease in the center and left side of the bed likely was due primarily to uptake by the plant. Feeder root development was extensive near the drip tube, and with adequate moisture always present in this area, $\mathrm{N}$ uptake would have been rapid and extensive. Further examination of the root systems failed to reveal any differences in root distribution patterns related to treatments.

These studies indicate that drip irrigation is an effective way to supply $\mathrm{N}$ to tomato plants. Increasing $\mathrm{N}$ application frequency was most beneficial at Clayton on a poorly buffered, light, sandy soil low in OM, where daily application of $\mathrm{N}$ increased total fruit yields compared with preplant, monthly, or biweekly $\mathrm{N}$ applications. On the heavier soil at Charleston, $\mathrm{N}$ application frequency did not influence tomato yields.

\section{Literature Cited}

Bar-Yosef, B. 1977. Trickle irrigation and fertilization of tomatoes in sand dunes: Water, $\mathrm{N}$, and $\mathrm{P}$ distributions in the soil and uptake by plants. Agron. J. 69:486-491.

Bar-Yosef, B. and M.R. Sheikholslami. 1976. Distribution of water and ions in soils irrigated and fertilized from a trickle source. Soil Sci. Soc. Amer. Proc. 40:575-582.

Bernstein, L. and L.E. Francois. 1973. Comparisons of drip, furrow and sprinkler irrigation. Soil Sci. 115:73-86.

Bhella, H.S. 1986. Effect of plastic mulch and trickle irrigation on tomato growth, yield, and nutrition. HortScience 21:86-88.

Bresler, E. 1975. Two-dimensional transport of solutes during non-steady infiltration from a trickle source. Soil Sci. Amer. Proc. 39:604613.

Cook, W.P., D.O. Ezell, R.P. Griffin, C.E. Drye, and P.J. Rathwell 1980. Commercial tomato production in South Carolina. Clemson Univ. Coop. Ext. Serv. Bul. 625.

Doss, B.D., J.L. Turner, and C.E. Evans. 1980 Irrigation methods and in-row chiseling for tomato production. J. Amer. Soc. Hort. Sci. 105:611-614.

Elmstrom, G.W., S.J. Locascio, and J.M. Myers. 1981. Watermelon response to drip and sprinkler irrigation. Proc. Fla. State Hort. Soc. 94:161-163.

Fiskell, J.G.A. and S.J. Locascio. 1983. Changes in available $\mathrm{N}$ for drip-irrigated tomatoes from preplant and fertilization N sources. Soil\& Crop Sci. Soc. Fla. Proc. 42:180-184.

Hall, B.T. 1974. Staked tomato drip irrigation in California, Proc. 2nd Intl. Drip Irr. Congr., San Diego. p. 480-485.

Isobe, M. 1974. Investigations in sugar-cane fertilization by drip irrigation in Hawaii. Proc. 2nd Intl. Drip Irr. Congr., San Diego. p. 405--410.

Karlen, D.L. and M.L. Robbins. 1983. Management practices for fresh-market tomato production in the southeastern coastal plain. HortScience 18:732-734.

Keeney, D.R. and D.W. Nelson. 1982. Nitrogen 
in organic forms. Agronomy 9:643-698.

Locascio, S.J. and J.M. Myers. 1974. Tomato response to plug-mix, mulch and irrigation method. Proc. Fla. State Hort. Soc. 87:126130.

Locascio, S.J., J.M. Myers, and F.G. Martin.
1977. Frequency and rate of fertilization with trickle irrigation for strawberries. J. Amer. Soc. Hort. Sci. 102:456-458.

Miller, R.J., D.E. Rolston, R.S. Rauschkolb, and D. W. Wolf. 1981. Labeled nitrogen uptake by drip-irrigated tomatoes. Agron. J. 73:265-270.
Tanaka, A., K. Fujita, and K. Kikuchi. 1974. Nutrio-physiological studies on the tomato plant. 1. Outline of growth and nutrient absorption. Soil Sci. Plant Nutr. 20:57-68.

Tecator Manual. 1982. Kjeltic system 1003 distilling unit. Tecator, Hoganas, Sweden. 